\title{
MALAYSIAN MEGA SCIENCE FRAMEWORK: THE NEED FOR SOCIAL IMPACT AND SUSTAINABILITY ASSESSMENT
}

\author{
Zainal A. Ahmad \\ College of Graduate Studies, \\ Universiti Tenaga Nasional (UNITEN), \\ 43000 Kajang, Selangor, Malaysia \\ e-mail: azainal@uniten.edu.my
}

and

\author{
Zulfadli Ahmad \\ College of Engineering \\ Universiti Tenaga Nasional (UNITEN), \\ 43000 Kajang, Selangor, Malaysia \\ e-mail: zulfadlibinahmad@gmail.com
}

\begin{abstract}
This review focuses on issues surrounding wastewater management as part of the National Sustainable Development (2013-2050) under the Malaysian Mega Science Framework. In line with the national priority area of water security, this review will highlight the technical reports compiled by the Academy of Sciences Malaysia (ASM) on the challenges of water resource development and wastewater management and treatment. The discussion will dwell on the social impact of pollution in water and wastewater and mitigation plans that need to be put in place to ensure sustainable national development and making water as a National Key Economic Area (NKEA).
\end{abstract}

Key Words: Mega Science Framework, Wastewater Management, Water Resources Development, Sustainable Development, Social Impact, Sustainability Assessment.

\section{INTRODUCTION}

The Malaysian Mega Science Framework was initiated by the Academy of Sciences Malaysia in 2011 with the objective of identifying Science, Technology, and Innovation (STI) opportunities and prepare recommendations and roadmap for short, medium and long-term (2011-2050). The aspiration of the Framework is the maximum use of STI in sustaining the country's development for a prosperous, peaceful and progressive country and its people in the next 50 years (Academy of Sciences Malaysia, 2014). One of the key rationales underlying this framework is that whereas science, engineering and innovation are increasingly central to sustainable development, elements of STI must be integrated into the national sustainable development plan in order to introduce rational policies that reflect better understanding of complex technical, economic, social, cultural and ethical issues concerning the society, the earth, and its environment. In 2011, the first phase Mega Science 1.0 focused on Water, Energy, Health, Agriculture, and Biodiversity and in 2013, the second phase Mega Science 2.0focused on Infrastructure, Housing, Transportation, Environment, Electrical and Electronics. The Academy hosted a series of stakeholder engagement workshops with scientists, practitioners, academics, 
government agencies, parliamentarians, and the general public to discuss issues and challenges (opportunities, benefits, barriers, problems) on current sustainable practices in order to generate recommendations for policy makers and responsible parties. Water pollution was one of the key issues raised for Water agenda in Mega Science I.0 as it was increasing parallel with the rapid development in Malaysia. This was further explored under Environment in Mega Science 2.0.Therefore, this paper explores the challenges of water resource development and wastewater management and treatment and the social impact of the recommended mitigation plans.

\section{LITERATURE REVIEW}

\section{Water Resources Development}

Comprising over 70 per cent of the Earth's surface, water is undeniably the most valuable natural resource existing on our planet. For Malaysia, the Water agenda of the Mega Science 2.0 highlights various challenges, specifically water pollution management within the context of water resources development. Water resources can be developed through water recycling, groundwater, rainwater harvesting, flood/runoff storage, desalination and atmospheric capture as shown in Table 1. Sim (2014) raised several concerns for sustaining the water resources, namely pollutants in wastewater through sewer mining and storm water recovery. Pollution of water resources is a common incident (Han and Wei, 2009; Li et al., 2010). Whereas many regulations such as the Environmental Quality Act (1974) are in place, Sim (2014) questioned whether they are effective in addressing water pollution either direct (point source pollution) or indirect (non-point source pollution) in Malaysia.

Table 1

\section{Water Resources Development}

\begin{tabular}{|c|c|c|c|c|c|c|}
\hline & Water Recycling & Groundwater & $\begin{array}{l}\text { Rainwater } \\
\text { Harvesting }\end{array}$ & $\begin{array}{c}\text { Flood/Runoff } \\
\text { storage }\end{array}$ & Desalination & $\begin{array}{l}\text { Atmospheric } \\
\text { Capture }\end{array}$ \\
\hline Source & $\begin{array}{l}\text { Sewer mining. } \\
\text { Stormwater } \\
\text { recovery. }\end{array}$ & $\begin{array}{l}\text { Aquifer } \\
\text { abstraction/ } \\
\text { recharge. }\end{array}$ & $\begin{array}{l}\text { Rainwater } \\
\text { capture and } \\
\text { storage. }\end{array}$ & $\begin{array}{l}\text { Divest runoff } \\
\text { from river to } \\
\text { holding ponds. }\end{array}$ & $\begin{array}{l}\text { Removal of } \\
\text { mineral from } \\
\text { seawater. }\end{array}$ & $\begin{array}{l}\text { Water } \\
\text { abstraction } \\
\text { from humid } \\
\text { ambient air. }\end{array}$ \\
\hline Uses & $\begin{array}{l}\text { Indirect potable } \\
\text { reuse (e.g. } \\
\text { NEWater). } \\
\text { Irrigation and } \\
\text { factory process } \\
\text { water. } \\
\text { Recharging of } \\
\text { aquifer augmenting } \\
\text { environmental flow. }\end{array}$ & $\begin{array}{l}\text { Industrial } \\
\text { supply. } \\
\text { Augmented } \\
\text { potable supply. } \\
\text { Bottled water. } \\
\text { Aquifer storage } \\
\text { and recovery. } \\
\text { River bank } \\
\text { filtration. }\end{array}$ & $\begin{array}{l}\text { Supplement } \\
\text { water supply } \\
\text { (non-potable). } \\
\text { Emergency } \\
\text { storage. } \\
\text { Reduced } \\
\text { stormwater } \\
\text { runoff into } \\
\text { river. }\end{array}$ & $\begin{array}{l}\text { Emergency } \\
\text { storage for } \\
\text { water supply. } \\
\text { Augmenting } \\
\text { water treatment } \\
\text { plant operations. } \\
\text { Reduce floods } \\
\text { by diverting } \\
\text { flood runoff. }\end{array}$ & $\begin{array}{l}\text { Industry supply. } \\
\text { Potable water } \\
\text { supply. }\end{array}$ & $\begin{array}{l}\text { Potable water } \\
\text { supply. } \\
\text { Doubles as an } \\
\text { air conditioner } \\
\text { (potable units) } \\
\text { Available for } \\
\text { small to large } \\
\text { capacity units. }\end{array}$ \\
\hline Issues & $\begin{array}{l}\text { Efficiency of system } \\
\text { to remove human } \\
\text { pathogens and } \\
\text { biological active } \\
\text { molecules. } \\
\text { Public perception. }\end{array}$ & $\begin{array}{l}\text { Lack of } \\
\text { regulations and } \\
\text { enforcement of } \\
\text { industry. } \\
\text { Environmental } \\
\text { degradation. } \\
\text { Over } \\
\text { exploitation. } \\
\text { Transboundary } \\
\text { aquifer. }\end{array}$ & $\begin{array}{l}\text { Cost outlay for } \\
\text { unit. } \\
\text { Low water } \\
\text { pricing makes } \\
\text { this option not } \\
\text { attractive. } \\
\text { Mandatory } \\
\text { requirements } \\
\text { but not } \\
\text { enforced. }\end{array}$ & $\begin{array}{l}\text { Pollution issues. } \\
\text { Large land area } \\
\text { required. } \\
\text { High capital } \\
\text { cost. }\end{array}$ & $\begin{array}{l}\text { High infra- } \\
\text { structure and } \\
\text { operational costs. } \\
\text { Requires large } \\
\text { amounts of } \\
\text { electricity to run. } \\
\text { Environmental } \\
\text { issues - salt } \\
\text { residues. }\end{array}$ & $\begin{array}{l}\text { High energy } \\
\text { requirement } \\
\text { for harvesters. } \\
\text { High cost. }\end{array}$ \\
\hline
\end{tabular}

Source: Sim (2014). 


\section{Pollution in Water and Wastewater}

Water pollution can be derived from two general categories of sources: direct and indirect contaminant sources. Direct sources or point source pollution includes sewage outfalls from refineries, industries and waste treatment plants. On the other hand, indirect sources or non-point source pollution include contaminants that enter the water supply from ground water systems and from the atmosphere by rainwater (Zhao, 2010). Further, contaminants can be arranged under two broad classes, organic and inorganic. Some organic water pollutants include manufacturing solvents, inconstant organic compounds, pesticides (Zhao, 2010), insecticides (Xu et al., 2010) and food processing wastes, and others. Inorganic water pollutants consist of metals, fertilizers and acidity caused by industrial discharges (Vijayaraghavan and Yun, 2008).

Many industries are using metals extensively, including metallurgical, mining, electroplating, electronic and metal finishing. Metals are toxic both to lower and higher organisms. Occasionally metals may accumulate to toxic levels and cause ecological damage (Jefferies and Firestone, 1984). Metals such as lead, mercury, cadmium, chromium and uranium are regarded as toxic; whereas copper, cobalt and zinc are not as toxic. However their frequent usage and increasing level in the environment becomes an important issue (Brown and Absanullah, 1971; Volesky, 1990). They are not selfdegradable and can accumulate in living organisms, causing severe disorders and diseases (Tran et al., 2010).

Water pollution impacts on the society, the earth, and its environment were further explored by the Academy of Sciences Malaysia in Mega Science 2.0. Water pollution will lead to reduced water resources, demand high economic cost for cleanup, contaminated lands and habitat degradation and the social impacts include social and health issues and lower quality of life in Malaysia. The Academy was driven to conduct a comprehensive review of the technical, economic, social, cultural and ethical issues concerning water pollution and recommend mitigation plans. The rest of this review will look at the wastewater management. The Mega Science 2.0 also calls for the implementation of the National Water Resources Policy (2012) and the National Water Resources Act to protect water rights for all, but more importantly to integrate the water resources management and wastewater management which are presently under different jurisdictions at the federal and state levels.

\section{Wastewater Management and Treatment Technology}

Technologies for treating industrial wastewaters are chemical, physical, and biological methods. Chemical methods include chemical precipitation, chemical oxidation or reduction, formation of an insoluble gas followed by stripping, and other chemical reactions that involve exchanging or sharing electrons between atoms. Physical treatment methods include sedimentation, flotation, filtering, stripping, ion exchange, adsorption, and other processes that accomplish removal of dissolved and undissolved substances without necessarily changing their chemical structures. Biological methods are those that involve living organisms using organic, or in some instances, inorganic, substances for food, completely changing their chemical and physical characteristics. As a general rule, biological treatment is more economical than any other type of treatment, when reasonably complete treatment is required, and whenever it can be made to work successfully (Woodart, 2001).

Conventional methods for removing metal ions from aqueous solution have been studied in detail, such as chemical precipitation, ion exchange, electrochemical treatment, membrane technologies, adsorption on activated carbon etc. However, chemical precipitation and electrochemical treatment are ineffective, especially when metal ion concentration in aqueous solution is as low as 1 to $100 \mathrm{mg} / \mathrm{L}$, they also produce large amount of sludge to be treated with great difficulties. lon exchange, 
membrane technologies and activated carbon adsorption process are expensive, especially when treating a large amount of water and wastewater containing heavy metal in low concentration, so they cannot be used at large scale (Wang and Chen, 2006). Much has been discussed about their downside aspects in recent years (Atkinson et al., 1998; Crini, 2006), which can be summarized as expensive, not environment friendly and usually dependent on the concentration of the waste.

Recently, research attention has been focused on biological methods for the treatment of effluents, some of which are in the process of commercialization (Anirudhan and Radhakrishnan, 2009; Bhatnagar and Sillanpaa, 2009; Dias et al. 2011). There are three principle advantages of biological technologies for the removal of pollutants; first, biological processes can be carried out in situ at the contaminated site; Second, bioprocess technologies are usually environmentally kind (no secondary pollution) and third, they are cost effective (Loukidou et al., 2003). In looking at waste or wastewater as resource, Sim (2014) highlighted the need to explore bio-effluent in reclamation for non-potable reuse of wastewater, or biosolids in nutrient recovery and soil amendments as well as biogas for renewable energy generation.

\section{DISCUSSION}

The preceding review highlights the challenges in water resources development and the need for further exploration of water pollution technology as mitigation plans to address the economic and social impacts of wastewater pollution. Among the many recommendations, the Mega Science 2.0 proposed several mitigation plans for the period 2013 to 2050 for Water and Wastewater Treatment System as shown in Table 2 (Sim, 2014):

Table 2

Mitigation Plans for Water and Wastewater Treatment System (2013 to 2050)

\begin{tabular}{|l|l|}
\hline Timeline & Mitigation Plan \\
\hline 2013-2020 & $\begin{array}{l}\text { R\&D for innovative watertreatment technologies, e.g. using solar enegy systems,recover } \\
\text { useful byproducts, e.g. Methane, H2 gas. } \\
\text { Improve efficiency andperformance of existingsewage treatment. } \\
\text { More advance R\&D onbio-solids and sludgemanagementtechnologies, e.g asfertiliser. } \\
\text { Incentive for SME -wastewater treatment plant. }\end{array}$ \\
\hline $2020-2035$ & $\begin{array}{l}\text { Pilot projects andefficiency assessment oftechnology. } \\
\text { Combined sewer/stormwater systemsadoption - segregation fordesignated } \\
\text { treatmenttechnologies - more efficient\& economical. }\end{array}$ \\
\hline $2035-2050$ & $\begin{array}{l}\text { Commercialization oftechnology and services. } \\
\text { Industrial implementation of bioeffluent/biosolids/biogas systems. } \\
\text { Water and EcologicalSustainability. } \\
\text { Water and Wastewater. } \\
\text { Treatment Systems. }\end{array}$ \\
\hline
\end{tabular}

Whereas these recommendations address the environmental impacts of reduced water resources, economic cost for cleanup, contaminated lands, and habitat degradation, much is left to be desired in investigating the social impacts of water pollution which give rise to social and health issues and lower quality of life. For example, there are environmental studies on the impact of pollutants on coastal areas such as the Tunku Abdul Rahman Marine Park (Md Suhaimi Elias et al., 2011). However, we need more broad-based social impact studies, for example Tran, Euan, and Isla (2002)on the impact of water pollution on the livelihood of a small coastal community whereby public perceptions of the locals were 
sought. They raised concerns about the need for environmental education and public awareness campaign as well as a well-planned moderate development plan. The same should be done in Malaysia through coordinated sustainability assessments and social impact assessments throughout the country. Singh et al. (2012) reviewed 41 indices from various sustainability assessment methodologies based on international efforts on measuring sustainability. However, only few of them have an integral approach of environmental, economic and social aspects. Further, Singh et al. (2012) argued that indicators of sustainable development should be selected, revisited and refined based on the appropriate communities of interest, thus the Academy will be best served by integrating sustainability assessment within the Mega Science Framework.

\section{CONCLUSION}

This review focuses on issues surrounding wastewater management under the Mega Science Framework (2013-2050) to ensure national sustainable development for Malaysia. In highlighting the issues and challenges of water resources development and wastewater management and treatment in the country, the mitigation plans recommended the Academy of Sciences Malaysia (ASM) can be further enhanced by integrating appropriate sustainability assessment methodologies and incorporate the social impacts of water and wastewater pollution to ensure sustainable national development.

\section{REFERENCES}

Academy of Sciences Malaysia (2014). The Mega Science Agenda: Malaysia 2050. Presentation $6^{\text {th }}$ February 2014, ASM, Matrade Centre, Kuala Lumpur.

Atkinson B.W., Bux, F. and Kasan, HC (1998). Considerations for application of biosorption technology to remediate metal-contaminated industrial effluents, Water SA; 24:129-35.

Anirudhan, T.S., and Radhakrishnan (2009). Improved performance of a biomaterial-based cation exchanger for the adsorption of uranium $(\mathrm{VI})$ from water and nuclear industry wastewater. Journal Environmental Radioactive, Vol. 100, pp. 250-257.

Bhatnagar, A. and Sillanpaa, M. (2009). Applications of chitin and chitosanderivatives for the detoxification of water and wastewater : A short review. Advances in Colloid and Interface Science, Vol 152, pp. 26-38.

Brown, B. and Absanullah, M. (1971).Effects of heavy metals on mortality and growth. Mar Pollut Bull.Vol. 2.pp.182-187.

Crini, G. (2006): Non-conventional low-cost adsorbents for dye removal: A review. Biores Technol, Vol. 97, pp. 1061-85.

Dias A.M.G.C., Hussain A., Marcos A.S. and Roque A.C.A. (2011). A biotechnological perspective on the application of iron oxide magnetic colloids modified with polysaccharides, Biotechnology Advances. Vol. 29, pp. 142-155.

Jefferies, D.J. and Firestone, P. (1984).Chemical analysis of some coarse fish from a Suffolk river carried out as part of the preparation for the first release of captive-bred otters. Journal Otter Trust. Vol. 1, pp.17-22. 
Han, L. and Wei, L. (2009). The numerical simulation on the impact of multiple random pollution sources on water quality. Bioinformatic and Biomedical Engineering, pp. 1-4.

Li, S., Gong, H., Wang, S. and Wang, Z. (2010).Analysis of urban water quality based on GIS. Geoinformatic, pp.1-4.

Loukidou M.X., Matis K.A., Zouboulis A.I., and Kyriakidou M.L. (2003). Removal of As(V) from wastewaters by chemically modified fungal Biomass. Water Resources. Vol. 37 pp. 4544-4552.

Md Suhaimi Elias, Ab Khalik Wood, Zaleha Hashim, Mohd SuhaimiHamzah, Shamsiah Ab Rahman, Nazaratul Ashifa Abdullah Salim (2011). Sources Of Polycyclic Aromatic Hydrocarbons (PAHS)Pollution In Marine Sediment From Tuanku Abdul Rahman National Park, Sabah. The Malaysian Journal of Analytical Sciences, Vol 15(2), pp. 295-302

Sim, L. K. (2014). Mega Science Framework Study for Sustained National Development (2013-2050) for Environment Sector: Water. Presentation $6^{\text {th }}$ February 2014, ASM, Matrade Centre, Kuala Lumpur.

Singh, R. K., Murty, H.R.,Gupta, S.K., Dikshit, A.K. (2012). An overview of sustainability assessment methodologies. Ecological Indicators. Vol. 15, pp. 281-299.

Tran Hoang Vinh, Tran Lam Dai, Thinh Ngoc Nguyen (2010). Preparation of chitosan/magnetite composite beads and their application for removal of $\mathrm{Pb}(\mathrm{II})$ and $\mathrm{Ni}(\mathrm{II})$ from aqueous solution. Materials Science and Engineering. Vol. 30, pp. 304-310.

Tran, K. C., Euan, J. and Isla, M. L. (2002).Public perception of development issues: Impact of water pollution on a small coastal community Ocean \& Coastal Management. Vol. 45, pp. 405-420.

Vijayaraghavan, K. and Yun, Y-S. (2008). Bacterial biosorbents and biosorption, Biotechnology Advances. Vol. 26(3), pp. 266-291.

Volesky, B. (1990). Biosorption of heavy metals.CRC press, pp. 140-171.

Wang J.L. and Chen C. (2006).Biosorption of heavy metals by Saccharomyces cerevisiae: a review. Biotechnology Advances. Vol. 24, pp. 427-451.

Woodart, F. (2001). Industrial Waste Treatment Handbook. Butterworth - Heinemann.

Xu, H., Wang, L., Guoguang, L. and Liqing, Z. (2010). Evaluation on joint acute toxicity of BetaCypermethrin and Chlorpyrifos to freshwater protozoan community. Bioinformatic and Biomedical Engineering.

Zhao, Y. (2010). Pesticide pollution to water environment of three gorges reservoir area.Challenges in Environmental Science and Computer Engineering, Vol. 1, pp.77-80. 